\title{
A LONG TERM STUDY OF THE VARIATION OF SERUM CHOLESTEROL IN MAN ${ }^{1}$
}

\author{
BY KENNETH B. TURNER AND ALFRED STEINER \\ (From the Research Division of Chronic Diseases, Department of Hospitals, City of New: \\ York, and the Department of Medicine, College of Physicians and Surgeons, \\ Columbia University, and the Presbyterian Hospital, New York City)
}

(Received for publication August 30, 1938)

Although there are innumerable reports on the blood cholesterol of man under normal or abnormal conditions, most of these are based on single or, at best, a few determinations on a given individual. While there has developed an increasing realization that the variation or the lack of change in the level of blood cholesterol of the individual under a certain set of conditions is of paramount importance, reports of such variations are meager.

An unusual opportunity was afforded us to study the serum cholesterol of a group of hospitalized but not acutely ill patients at approximately weekly intervals for a year or more.

\section{MATERIAL AND PLAN OF STUDY}

There were 10 patients in the group. The following 9 of these were studied for 12 to 14 months: D. C., a Negro of 21 years, with inactive rheumatic heart disease; M. C., a white male, age 62 , with hypertensive vascular disease; $M$. Cl., a white female, age 55 , with diabetes; H. F., a white female, age 42 , with tabes dossalis; F. K., a white male, age 64 , with diabetes; J. N., a white male, age 52 , with peptic ulcer; J. O., a white male, age 44 , with inferior vena cava obstruction; A. P., a white female, age 79, with general arteriosclerosis and hypertensive vascular disease; and T. R., a white male, age 71 , with general arteriosclerosis. The tenth case, B. S., a white male of 38 , with syphilis and cerebral thrombosis, was under observation for 7 months.

The period of observation began in the late Fall of 1936 and extended to the Winter of 1937-1938. During this time the basic diet consisted of 350 grams of carbohydrate, 100 grams of protein and 115 grams of fat daily. The diabetics, however, were given 160 grams carbohydrate, 75 grams protein, and 90 grams of fat daily. The patients were weighed each week because of the possible bearing of the state of nutrition on the level of the serum lipids (8). It may be mentioned here that no significant fluctuation in weight took place in any case. Monthly blood counts were obtained and remained constant. The basal metabolic rate was determined each month and did not vary significantly except for an expected rise during thyroid administration. The serum

1 Read by title before the American Society for Clinical Investigation, May 2, 1938. cholesterol of each patient was determined at weekly intervals by the method of Bloor, Pelkan, and Allen (2).

The plan of study for each case was similar. After a control period of about 2 months during which a base line for the serum cholesterol was established and observations were made on the variation of serum cholesterol from hour to hour, the patient was given potassium iodide or thyroid for 4 to 6 weeks and the fat content of the diet was raised or lowered for a similar period. Following each of these experimental periods, 4 or 5 weeks as a rule were allowed to pass to obtain further control observations. However, the high fat and low fat feeding periods were consecutive in order to heighten by contiguity any effect secured. After the thyroid administration it was necessary to allow 4 to 6 weeks for the serum cholesterol to stabilize before beginning a control period, and the determinations made during these post-thyroid weeks were discarded.

Figure 1 shows the serum cholesterol values for $\mathrm{Pa}$ tient $T$. R. during the entire period of study lasting for 62 weeks. It illustrates the temporal relationships in a typical case according to the plan just outlined.

\section{Variation during 24-hour periods}

It was stated above that, during the first control period when the fasting serum cholesterol was being determined for each patient at weekly intervals, opportunity was presented to perform repeatedly so-called "cholesterol tolerance tests" upon the group of cases.

There are many conflicting statements in the literature as to the stability of the blood cholesterol values during a day with or without the ingestion of a high fat meal. The following reports should be regarded as typical but in no sense a complete survey of the subject.

Bruger and Somach (4) found an average standard deviation of \pm 8.0 per cent in the whole blood cholesterol over a 24-hour period independent of the ingestion of food. McEachern and Gilmour (10) noted an individual variation of 25 to $84 \mathrm{mgm}$. with an average of $40 \mathrm{mgm}$. in 28 normal fasting humans over a 5-hour period. On the other hand, Boyd (1) found only slight 


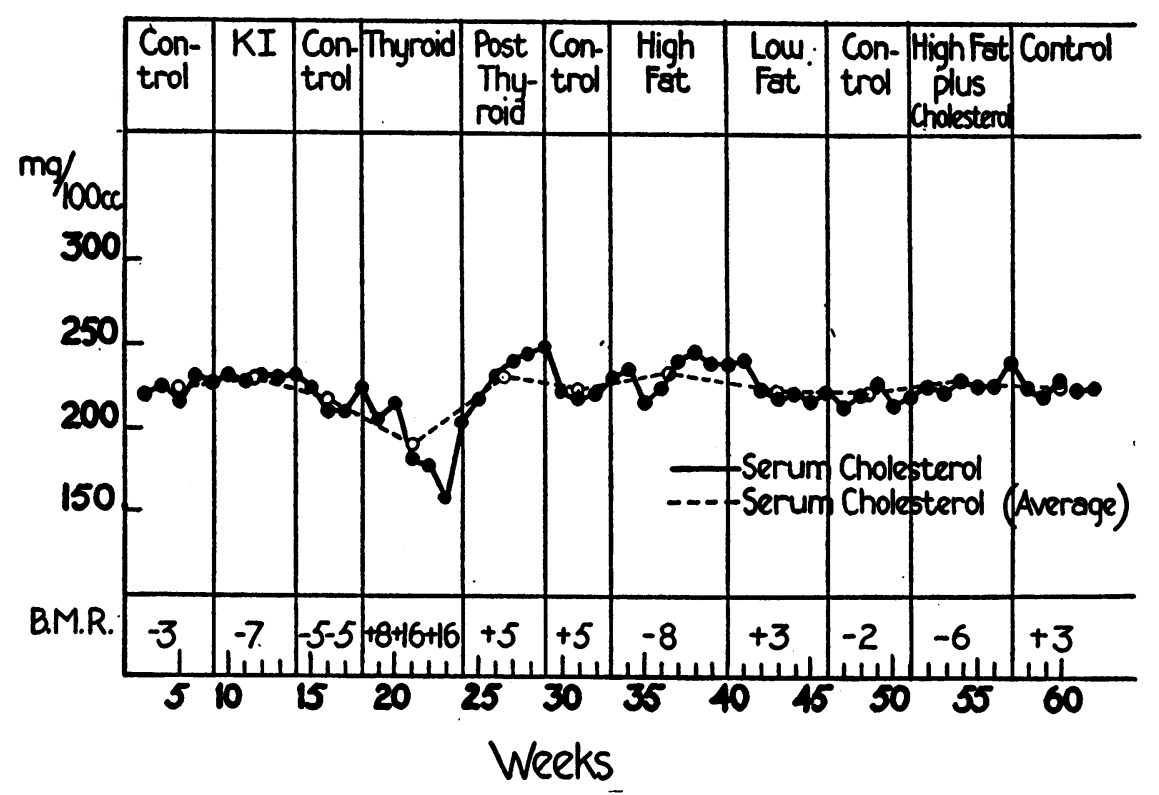

Fig. 1. The Weekly Serum Cholesterol levels of a Single Patient, T. R., During a Period of Observation of 62 Weeks

variations in an individual during a 24-hour period regardless of food, exercise, and so on.

After a fat meal, Hiller, Linder, Lundsgaard, and Van Slyke (6) found no significant change in the plasma cholesterol of either normals or nephritics. Mjassnikow (11) detected no rise in blood cholesterol in normals or in patients with liver disease, but found an increase regularly in nephrotics. Blotner (3) reported that normal or malnourished individuals show no increase in plasma cholesterol after $500 \mathrm{cc}$. of 20 per cent cream, but that a rise occurs in obese patients or those with diabetes insipidus.

In the present group of 10 cases, 44 tests were made as follows. A blood was taken for analysis at 8 a.m. with the patient in the fasting state. Breakfast consisted of fruit, 2 eggs, buttered toast, coffee, and $200 \mathrm{cc}$. of milk to which 20 grams of cholesterol had been added. Dinner and supper were served at the usual hours. Additional bloods were taken at 10 a.m., noon, 4 p.m., and 8 a.m. of the following day.

The results of a single test on each of 5 patients are shown in Table $I$. They are typical of the whole group.

It is clearly shown that there was little or no change in the total serum cholesterol during the course of 24 hours. This tendency of the serum
TABLE I

Serum cholesterol during 24-hour periods

\begin{tabular}{|c|c|c|c|c|c|c|c|c|c|c|}
\hline \multirow{2}{*}{ Patient } & \multicolumn{5}{|c|}{$\begin{array}{l}\text { Total serum cholesterol } \\
(\mathrm{mgm} \text {. per } 100 \mathrm{cc} .)\end{array}$} & \multicolumn{5}{|c|}{$\begin{array}{l}\text { Ester cholesterol } \\
\text { (mgm. per } 100 \text { cc.) }\end{array}$} \\
\hline & $\begin{array}{l}8.00 \\
\text { a.m. }\end{array}$ & $\begin{array}{l}10.00 \\
\text { a.m. }\end{array}$ & $\frac{12.00}{\mathrm{M} .}$ & $\begin{array}{l}4.00 \\
\text { p.m. }\end{array}$ & $\begin{array}{l}8.00 \\
\text { a.m. }\end{array}$ & $\begin{array}{l}8.00 \\
\text { a.m. }\end{array}$ & \begin{tabular}{|l}
10.00 \\
a.m.
\end{tabular} & $\begin{array}{c}12.00 \\
\mathbf{M} .\end{array}$ & $\begin{array}{l}4.00 \\
\text { p.m. }\end{array}$ & $\begin{array}{l}8.00 \\
\text { a.m. }\end{array}$ \\
\hline & $\begin{array}{l}238 \\
241 \\
286 \\
255 \\
220\end{array}$ & $\begin{array}{l}230 \\
236 \\
284 \\
240 \\
236\end{array}$ & $\begin{array}{l}226 \\
233 \\
278 \\
256 \\
219\end{array}$ & $\begin{array}{l}238 \\
242 \\
290 \\
245 \\
238\end{array}$ & \begin{tabular}{|l|}
228 \\
241 \\
272 \\
250 \\
219
\end{tabular} & \begin{tabular}{|l|}
165 \\
180 \\
192 \\
165 \\
166
\end{tabular} & \begin{tabular}{|l|}
160 \\
152 \\
168 \\
179 \\
146
\end{tabular} & \begin{tabular}{|l}
150 \\
166 \\
175 \\
160 \\
158
\end{tabular} & \begin{tabular}{|l|}
170 \\
165 \\
185 \\
188 \\
160
\end{tabular} & $\begin{array}{l}164 \\
174 \\
181 \\
186 \\
145\end{array}$ \\
\hline
\end{tabular}

cholesterol to be maintained at a constant level during the day regardless of feeding was striking in each of the 10 patients studied. Such fluctuations as occurred were inconstant and apparently casual, resulting, perhaps, from errors in technique or from unknown causes. The possibility of their being the result of changes in hemoconcentration was investigated but no relationship could be demonstrated. The cholesterol ester varied more widely, but again according to no set pattern.

In order to broaden the scope of this phase of our observations, the same procedure was employed upon an additional group of 25 patients more acutely ill and representing a variety of disease entities. In these cases also it was ap- 
parent that the serum cholesterol did not fluctuate significantly during the 24-hour period.

\section{Variation during a year}

McClure and Huntsinger (9) analyzed 4 blood samples from each of 5 patients over a period of weeks or months and concluded that there was considerable variation in the cholesterol. This view was concurred in by Pucher and Sly (14) but was opposed by Robinson (15) as the result of a few observations on 2 cases. In a more extensive study, Schube (16) determined the whole blood cholesterol of 10 patients at weekly intervals for 16 weeks and found a maximum deviation of approximately $40 \mathrm{mgm}$. from the mean for each case. Sperry (18) made 2 or more determinations of the serum cholesterol of 25 healthy adults at varying intervals, and found a maximum variation of 12.3 per cent from the average, while in 17 instances this variation was 6.2 per cent or less. From this he concluded, "In most, if not all, persons in health the amount of cholesterol in the serum appears to be maintained at a constitutional level which is characteristic for each individual and from which large deviations do not ordinarily occur."

In our series, the determination of the normal variation in the serum cholesterol was based on a study of 4 control periods. The first of these came at the beginning of the year's observation and lasted about 2 months. The second followed the period of potassium iodide administration and lasted 4 to 6 weeks. The third was of similar length and began 4 to 6 weeks after a period when thyroid was given. The fourth came at the end of the year following periods of high and low fat feeding and was 4 to 10 weeks long.

The level of the serum cholesterol for each individual tended to remain relatively constant during each of the 4 control periods, although these were separated by intervals of as much as 3 months. Based on the combined results for the 4 control periods, the first columns of Table II show the maximal range and average for each patient. When the single determination of the total serum cholesterol farthest from the average is considered, the variation ranges from 4 per cent (B. S.) to 15 per cent (H. F.) with less than 10 per cent in 6 cases.
TABLE II Effect of $K I$ and thyroid on serum cholesterol

\begin{tabular}{|c|c|c|c|c|c|c|c|c|c|c|}
\hline \multirow{3}{*}{ Patient } & \multicolumn{3}{|c|}{ Control perlods } & \multicolumn{3}{|c|}{ KI period } & \multicolumn{3}{|c|}{ Thyroid period } & \multirow{3}{*}{$\begin{array}{l}\text { Change in } \\
\text { basal } \\
\text { metabolio } \\
\text { rate }\end{array}$} \\
\hline & \multicolumn{2}{|c|}{$\begin{array}{c}\text { Total } \\
\text { cholesterol }\end{array}$} & \multirow[b]{2}{*}{ 点 } & \multicolumn{2}{|c|}{$\begin{array}{c}\text { Total } \\
\text { cholesterol }\end{array}$} & \multirow[b]{2}{*}{ 点 } & \multicolumn{2}{|c|}{$\begin{array}{c}\text { Total } \\
\text { cholesterol }\end{array}$} & \multirow{2}{*}{ 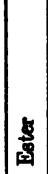 } & \\
\hline & 量 & $\frac{8}{8}$ & & 兽 & $\begin{array}{l}8 \\
8 \\
8 \\
\end{array}$ & & 煦 & $\begin{array}{l}8 \\
5 \\
5 \\
\end{array}$ & & \\
\hline $\begin{array}{l}\text { D.C. .. } \\
\text { M.C... } \\
\text { M.Ci. . } \\
\text { H.P. .. } \\
\text { F.K. .. } \\
\text { J.N.... } \\
\text { J.O.... } \\
\text { A.P.... } \\
\text { T.R. .. } \\
\text { B.8.... }\end{array}$ & $\begin{array}{c}\text { mom. } \\
\text { per } \\
100 \\
c c . \\
220-249 \\
336-401 \\
344-432 \\
237-308 \\
227-282 \\
277-341 \\
244-290 \\
305-358 \\
210-232 \\
265-287\end{array}$ & $\begin{array}{c}\text { mom. } \\
\text { per } \\
100 \\
c . \\
233 \\
368 \\
384 \\
280 \\
256 \\
308 \\
268 \\
334 \\
222 \\
276\end{array}$ & $\begin{array}{l}\text { per } \\
\text { cent } \\
\\
68 \\
71 \\
65 \\
66 \\
64 \\
70 \\
70 \\
71 \\
64 \\
67\end{array}$ & $\begin{array}{c}\text { mom. } \\
\text { per } \\
100 \\
c c . \\
220-250 \\
342-378 \\
385-462 \\
270-289 \\
226-250 \\
302-334 \\
255-280 \\
306-325 \\
228-232 \\
274-285\end{array}$ & $\begin{array}{c}\text { mom. } \\
\text { per } \\
100 \\
c c . \\
240 \\
363 \\
434 \\
280 \\
240 \\
320 \\
266 \\
322 \\
231 \\
280\end{array}$ & $\begin{array}{l}\text { per } \\
\text { cent } \\
\\
65 \\
62 \\
65 \\
69 \\
68 \\
69 \\
68 \\
75 \\
67 \\
58\end{array}$ & $\begin{array}{c}\text { mom. } \\
p \circ \\
100 \\
\propto c . \\
145-213 \\
240-400 \\
262-392 \\
204-250 \\
195-258 \\
200-331 \\
184-227 \\
218-318 \\
158-215 \\
207-256\end{array}$ & $\begin{array}{c}\text { mom. } \\
\text { per } \\
100 \\
c c . \\
180 \\
328 \\
329 \\
236 \\
226 \\
254 \\
208 \\
258 \\
190 \\
236\end{array}$ & $\begin{array}{l}\text { per } \\
\text { cent } \\
\\
65 \\
64 \\
70 \\
76 \\
61 \\
68 \\
62 \\
66 \\
66 \\
64\end{array}$ & $\begin{array}{r}-3 \text { to }+14 \\
-1 \text { to }+17 \\
-7 \text { to }+17 \\
+7 \text { to }+15 \\
-7 \text { to }+18 \\
0 \text { to }+14 \\
-9 \text { to }+7 \\
+8 \text { to }+38 \\
-5 \text { to }+16 \\
-10 \text { to }+20\end{array}$ \\
\hline
\end{tabular}

The levels of the cholesterol throughout the group average higher than has been usual in our experience. In 4 cases we should regard them as definitely above normal. The highest of these (M. Cl.) was a woman of 55 with well-controlled diabetes. M. C., a male of 62 years, had hypertensive vascular disease, as did A. P., a woman of 79. J. N. was a man of 52 with a healed peptic ulcer.

\section{Effect of potassium iodide}

Each patient was given 2 grams of potassium iodide daily for 4 to 6 weeks. This dose was well tolerated. There was no effect on the basal metabolic rate.

Table II shows the range and average of the total serum cholesterol and the average percentage of cholesterol ester. Similar figures for the control periods are given for comparison.

It is obvious that $\mathrm{KI}$ in this dosage for this length of time had no effect on the level of the total serum cholesterol or on the percentage of ester cholesterol in 9 of the 10 patients. In 1 case (M. Cl.), the female diabetic, the cholesterol values tended to be higher while $\mathrm{KI}$ was being given. The average for the $\mathrm{KI}$ period was 434 mgm. compared with $384 \mathrm{mgm}$. for the control periods. Whether or not the rise in serum cholesterol in this case is significant, we are unable to say.

\section{Effect of thyroid}

The administration of thyroid lasted 6 weeks in most cases. The dosage was determined by 
the reaction of the patient and the rise in basal metabolic rate. The daily dose of thyroid varied from 30 to $240 \mathrm{mgm}$. The results are shown in Table II.

It will be noted that in every case the total serum cholesterol fell. This is seen not only in the averages for the period but more accurately by comparing the lower figure of the range with the range of values for the control periods. Without exception a new low value is established during thyroid administration. The percentage of cholesterol esters is apparently uninfluenced.

A fall in blood cholesterol has been noted previously with thyroid administration $(5,7,13)$ although it has been emphasized that this fall does not occur in nephrosis $(12,17)$.

The basal metabolic rate was also increased in every case. This increase varied from 8 to 30 per cent with an average of 20 per cent.

When the thyroid administration was stopped, the serum cholesterol rose at varying rates toward control levels. Occasionally, it overshot previous values and then dropped back. During this stage of readjustment, which lasted 4 to 6 weeks, cholesterol determinations were discarded so far as the purposes of this paper were concerned.

\section{Effect of high or low fat diets}

Nine of the original 10 patients were available on whom to try the effect of diets high or low in fat. First they were given for 6 weeks a diet containing 300 grams of fat daily except in the case of the two diabetics whose basic diet of 160 C. -75 P. -90 F. was changed to 100 C.75 P. -200 F. The high fat intake was not pleasant, and it was with some difficulty that the patients were prevailed upon to carry through with it.

Without intermission the same patients were switched to a low fat diet containing less than 50 grams of fat daily. On this diet they remained for 6 weeks.

The results of the high fat and the low fat feeding on the serum cholesterol are shown in Table III.

Furthermore, at a later time, 3 of the patients again submitted themselves to the unpleasantness of the high fat diet, on this occasion supplemented daily by 10 grams of cholesterol in $200 \mathrm{cc}$. of
TABLE III Effect of diet on serum cholesterol

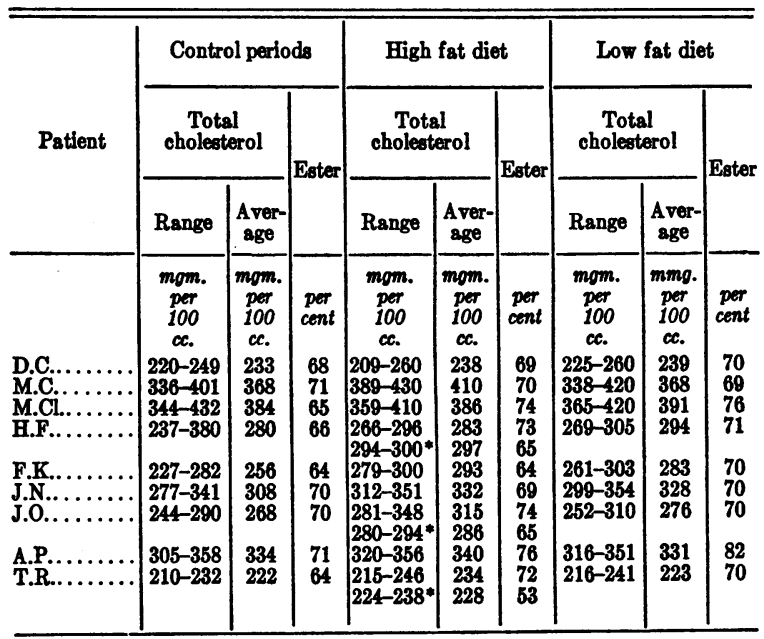

* High fat diet plus 10 grams of cholesterol daily.

milk, for another 6-week period. The results of this are also incorporated in Table III where they may be distinguished by asterisks.

In 5 of the 9 patients there was no increase in the total serum cholesterol during the period of high fat feeding. In 4 cases a slight rise seemed to occur. The significance of this in 2 cases (F. K. and J. N.) was somewhat nullified by the failure of the cholesterol level to fall substantially on a restricted fat intake. In a third case ( $J$. O.) the cholesterol did not show the same rise when the patient was again given a high fat diet with added cholesterol. Accordingly, it seems that too much emphasis should not be placed on these rises in serum cholesterol while on a high fat diet.

As for the addition of cholesterol to the high fat diet, it may be dismissed by saying that it was without effect when compared with the use of a high fat diet alone.

The total serum cholesterol values of patients on a low fat diet were in nowise different from those during the control periods.

With both diets, whether high or low in fat, the percentage of cholesterol ester rose slightly.

\section{SUMMARY}

1. The serum cholesterol of 9 patients was studied for 12 to 14 months, and in 1 case for 7 months.

2. The serum cholesterol of an individual tends to remain remarkably constant throughout the day, 
regardless of the feeding of a breakfast rich in cholesterol. This same constancy for the individual is evident from week to week and month to month.

3. Potassium iodide given in doses of 2 grams per day for 4 to 6 weeks has no effect on the serum cholesterol level of the individual.

4. Thyroid administration produced a sharp drop in serum cholesterol in every case. This was accompanied by a rise in the basal metabolic rate.

5. A diet high in fat seemed to cause a slight rise of dubious significance in the serum cholesterol of 4 of 9 patients. This increase was not augmented by the addition of cholesterol to the diet in 3 cases.

6. A diet low in fat failed to influence the level of the serum cholesterol.

\section{BIBLIOGRAPHY}

1. Boyd, E. M., Diurnal variations in plasma lipoids. J. Biol. Chem., 1935, 110, 61.

2. Bloor, W. R., Pelkan, K. F., and Allen, D. M., Determination of fatty acids (and cholesterol) in small amounts of blood plasma. J. Biol. Chem., 1922, 52, 191.

3. Blotner, $\mathrm{H}$., Blood fat tolerance tests in malnutrition and obesity. Arch. Int. Med., 1935, 55, 121.

4. Bruger, M., and Somach, I., The diurnal variations of the cholesterol content of the blood. J. Biol. Chem., 1932, 97, 23.

5. Duncan, A. G., The effect of thyroid administration on the blood cholesterol. J. Ment. Sc., 1931, 77, 332.

6. Hiller, A., Linder, G. C., Lundsgaard, C., and Van
Slyke, D. D., Fat metabolism in nephritis. J. Exper. Med., 1924, 39, 931.

7. Lévy, M., and Lévy, M., Le traitement de l'hypercholestérinémie par la thyroxine. Bull. Acad. de méd., Paris, 1931, 105, 666. (Chem. Abstr.)

8. Man, E. B., and Gildea, E. F., Serum lipoids in malnutrition. J. Clin. Invest., 1936, 15, 203.

9. McClure, C. W., and Huntsinger, M. E., Studies in fat metabolism. I. The influence on blood lipids of single foodstuffs. J. Biol. Chem., 1928, 76, 1.

10. McEachern, J. M., and Gilmour, C. M., Studies in cholesterol metabolism. I. Physiological variations in blood cholesterol. Canad. M. A. J., 1932, 26,30 .

11. Mjassnikow, A. L., Uber alimentäre Beeinflussung der Cholesterinämie beim Menschen. Ztschr. f. klin. Med., 1926, 103, 767.

12. Page, I. H., and Farr, L. E., The influence of high and low fat diets and thyroid substance on plasma lipids of nephrotic patients. J. Clin. Invest., 1936, 15, 181.

13. Parhon, C. I., and Ornstein, I., Influence de la thyroxine sur la cholestérolémie et la lipémie. Compt. rend. Soc. de biol., 1931, 108, 303.

14. Pucher, G. W., and Sly, G. E., Blood cholesterol: After fasting and after cholesterol ingestion. Bull. Buffalo Gen. Hosp., 1929, 7, 10.

15. Robinson, R. H. O. B., Diagnostic value of the estimation of blood cholesterol in cholelithiasis. Lancet, 1929, 2, 540.

16. Schube, P. G., Variations in the blood cholesterol of man over a time period. J. Lab. and Clin. Med., 1936, 22, 280.

17. Schwarz, H., and Kohn, J. L., Studies of nephritis in children. I. Nephrosis. Am. J. Dis. Child., 1922, 24, 125.

18. Sperry, W. M., The concentration of total cholesterol in the blood serum. J. Biol. Chem., 1937, $117,391$. 